\title{
Application of Enzymes in Sunflower Oil Extraction: Antioxidant Capacity and Lipophilic Bioactive Composition
}

\author{
Suellen A. O. Ribeiro, ${ }^{a}$ Antonio E. Nicacio, ${ }^{a}$ Ana B. Zanqui, ${ }^{a}$ Polyana B. F. Biondo, ${ }^{a}$ \\ Benício A. de Abreu-Filho, ${ }^{b}$ Jesui V. Visentainer, ${ }^{a}$ Sandra T. M. Gomes ${ }^{a}$ and \\ Makoto Matsushita*,a
}

\author{
${ }^{a}$ Departmento de Química and ${ }^{b}$ Departmento de Biologia, Universidade Estadual de Maringá, \\ 87020-900 Maringa-PR, Brazil
}

\begin{abstract}
A $2^{3}$ factorial design with center point in triplicate was used to evaluate the application of different enzymes in extraction of sunflower oil, comparing its quality with the oil obtained by conventional methods (solvent and pressing) in relation to antioxidant capacity, phytosterol and tocopherol contents, and fatty acid composition. Three enzymes were used; Pectinex Ultra SPL, Celluclast $1.5 \mathrm{~L}$ and Alcalase $2.4 \mathrm{~L}$; and three factors were evaluated: enzyme concentration, sample/water ratio and extraction time. Enzymatic aqueous extraction produced oil with better quality in relation to some of the evaluated parameters: highest antioxidant capacity against peroxyl radicals (371 $\mu \mathrm{mol}$ Trolox $\mathrm{g}^{-1}$ of oil), total phytosterols (183 mg $100 \mathrm{~g}^{-1}$ of oil) and omega-3 fatty acid content, as well the lowest content of saturated fatty acids. The application of enzymes in sunflower oil extraction represents an environmentally friendly methodology, free of toxic solvent residues and providing a final product of high quality.
\end{abstract}

Keywords: oilseed, clean method, enzymes, lipids, antioxidant capacity

\section{Introduction}

The sunflower grain (Helianthus annuus L.) is an oilseed that has wide adaptability to different soil and climatic conditions. ${ }^{1}$ Currently, it is grown mainly in the Russian Federation, Ukraine, Argentina, China and France, which are the top five global producers. ${ }^{2}$ One of the main destinations of the production of sunflower grain is the edible oil industry, since it has high oil content in its composition.

In industries, the oil extraction is performed mainly through techniques using solvents or by pressing, and both techniques are considered as conventional methods. The extraction process using solvents presents some disadvantages, such as the elimination of the solvent at the end of extraction, the use of non-renewable resources, the need for special care in its handling (high volatility and flammability of liquids), the toxicity of the solvents, the need for treatment of the residues, and alteration of the original product quality in relation to some important compounds, such as antioxidants and fat-soluble vitamins, which is especially caused by the high temperature reached in just a few steps. ${ }^{3}$

*e-mail: mmakoto@uem.br
Current trends in food production have demonstrated interest in alternative approaches for extraction of vegetable oils by clean techniques that are more environmentally friendly, ${ }^{4,5}$ since the use of solvents must be replaced by more sustainable technological processes, to meet the requirements of bodies ranging from government to environmental protection agencies. ${ }^{3}$

Enzymatic aqueous extraction is a green method, which consists of employing different enzymes which hydrolyze the cell wall and membranes of oleosomes, ${ }^{6}$ where the lipids are stored. Some studies have shown that the application of enzymes in the extraction of vegetable oils has improved the oils' quality.-9

One of the main problems with enzymatic extraction is the extraction yield and the cost of the enzymes. However, several studies have reported the optimization of this process using different enzymes, the development of demulsification steps to increase the percentage of free oil and the production of enzymes through solid state fermentation on a large scale using different low-cost agro-industrial residues as the substrate, which is very attractive, since it adds value by decreasing the cost of enzyme production and reducing the quantity of solid waste. ${ }^{10-14}$ 
This study aimed to evaluate the application of different enzymes (pectinase, cellulase and protease) in extraction of sunflower oil, comparing its quality with the oil obtained by conventional methods (solvents and pressing) in relation to antioxidant capacity, phytosterol and tocopherol contents, and fatty acid composition.

\section{Experimental}

\section{Sample preparation}

The sunflower grains were purchased in local market in Maringá-PR, Brazil. The grains were ground in a Wiley mill (Thomas Scientific, Swedesbroro, NJ, USA) to obtain a fine flour that was then sieved, using the fraction that passed through a 16 mesh Tyler series sieve (WS Tyler, Mentor, OH, USA). Pectinex Ultra SPL, Celluclast 1.5 L and Alcalase 2.4 L enzymes were obtained from SigmaAldrich (St. Louis, MO, USA).

\section{Enzymatic aqueous extraction}

The enzymatic aqueous extraction of sunflower oil was conducted from a $2^{3}$ factorial design with center point in triplicate (Table 1) using the Design Expert software, version 7.1.3. ${ }^{15}$ The extraction yield response was evaluated by the influence of different concentrations of Pectinex Ultra SPL, Celluclast 1.5 L and Alcalase 2.4 L enzymes, sample/water ratio and extraction time.

Table 1. Factors and levels for the $2^{3}$ factorial design with center point

\begin{tabular}{lcccccc}
\hline \multirow{2}{*}{ Factors } & Symbol & Unit & Type & \multicolumn{3}{c}{ Level } \\
\cline { 5 - 7 } & & & & -1 & 0 & +1 \\
\hline Enzymes & $\mathrm{X}_{1}$ & $\%$ & numeric & 6 & 8 & 10 \\
$\begin{array}{l}\text { Sample/ } \\
\text { Water }\end{array}$ & $\mathrm{X}_{2}$ & $\mathrm{~g} \mathrm{~mL}^{-1}$ & numeric & $1 / 6$ & $1 / 8$ & $1 / 10$ \\
time & $\mathrm{X}_{3}$ & hours & numeric & 4 & 6 & 8 \\
\hline
\end{tabular}

The extraction experiments were performed according to Santos and Ferrari ${ }^{16}$ with adaptations. Initially, the samples were subjected to heat treatment at $105{ }^{\circ} \mathrm{C}$ for $45 \mathrm{~min}$. In the first step, $5.0 \mathrm{~g}$ of sample was weighed and mixed with distilled water at a ratio of $1 / 6,1 / 8$ or $1 / 10\left(\mathrm{~g} \mathrm{~mL}^{-1}\right)$. The $\mathrm{pH}$ of the mixture was adjusted to 4.5 with $1.0 \mathrm{~mol} \mathrm{~L}^{-1}$ aqueous $\mathrm{HCl}$ solution and then added Pectinex Ultra SPL and Celluclast $1.5 \mathrm{~L}$ enzymes in concentrations of 6,8 and $10 \%(\mathrm{v} / \mathrm{v})$ of each single enzyme. Afterwards, the mixture was maintained at $50{ }^{\circ} \mathrm{C}$ for 4,6 and $8 \mathrm{~h}$, with shaking at $100 \mathrm{rpm}$ in an incubator shaker (CT 712, Cientec, Belo Horizonte, MG, Brazil). In the second step, the $\mathrm{pH}$ was adjusted to
7.0 through the addition of $1.0 \mathrm{~mol} \mathrm{~L}^{-1}$ aqueous $\mathrm{NaOH}$ solution followed by the addition of the Alcalase $2.4 \mathrm{~L}$ enzyme in concentrations of 6,8 and $10 \%(\mathrm{v} / \mathrm{v})$. Then, the sample was incubated at $55^{\circ} \mathrm{C}$ under the same conditions mentioned in the first step. After, the mixture was heated at $60{ }^{\circ} \mathrm{C}$ for $15 \mathrm{~min}$ and the extract was centrifuged for $15 \mathrm{~min}$. The free oil was collected with a micropipette and weighed to determine the extraction yield.

\section{Solvent extraction}

The sample was submitted to a lipid extraction process with a mixture of chloroform-methanol-water $(2: 2: 1.8, \mathrm{v} / \mathrm{v} / \mathrm{v})$ according to Bligh and Dyer. ${ }^{17}$

\section{Extraction by pressing}

For oil extraction by pressing, $100 \mathrm{~g}$ of sunflower grains ground and sieved (16 mesh), previously dried in a fan oven at $50{ }^{\circ} \mathrm{C}$ for about $14 \mathrm{~h}$, was placed in a stainless steel hydraulic cylinder (PHP Model 30 tons, Metal PEM Metallurgical, Maringa, PR, Brazil) under a pressure of 10 tons for $5 \mathrm{~h}$.

\section{Fatty acid composition}

Fatty acid methyl esters (FAME) of the sunflower oil were prepared by the methylation of lipids. ${ }^{18}$ The FAME were separated by gas chromatography (Trace Ultra 3300, Thermo Fisher Scientific, Waltham, MA, USA) equipped with a flame ionization detector (FID) and a cyanopropyl capillary column $(100 \mathrm{~m} \times 0.25$ i.d., $0.25 \mu \mathrm{m}$ film thickness, CP 7420 Varian). The injector, detector and gases conditions, and the main operational parameters were performed according to Sargi et al. ${ }^{19}$

Quantification of fatty acids was performed using tricosanoic acid methyl ester (Sigma-Aldrich, St. Louis, MO, USA) as an internal standard (23:0). ${ }^{20}$ Theoretical FID (flame ionization detector) correction factor values were used to obtain concentration values. ${ }^{21}$

\section{Phytosterols and tocopherols}

Phytosterols and tocopherols were simultaneously evaluated by gas chromatography with mass spectrometer (GC-MS). ${ }^{22}$ The extracted oils were previously derivatized ${ }^{23}$ and the analysis was performed in a gas chromatograph (Thermo Focus GC, Thermo Finnigan, Milan, Italy) equipped with a capillary column DB-5 (5\% phenyl, 95\% methylpolysiloxane) fused silica, $30 \mathrm{~m}, 0.25 \mathrm{~mm}$ i.d and $0.25 \mu \mathrm{m}$ thick film stationary phase (J\&W Scientific, 
Folsom, CA, USA) coupled to a mass spectrometer (DSQ II, Thermo-Finnigan, Milan, Italy) equipped with an electron ionization (EI) source. The conditions for analysis by GC-MS were described by Zanqui et al. ${ }^{24}$ Quantification was carried out in relation to the internal standard 5- $\alpha$-cholestane (Sigma-Aldrich, St. Louis, MO, USA). ${ }^{25}$

\section{Antioxidant capacity}

\section{DPPH radical assay}

The 2,2-diphenyl-1-picrylhydrazyl (DPPH) radical scavenging activity assay was performed as described in literature ${ }^{26,27}$ including modifications. ${ }^{28}$ The absorbance of the solutions was measured at $517 \mathrm{~nm}$ using a ultravioletvisible (UV-Vis) spectrophotometer (Genesys 10S, Thermo Fisher Scientific, Waltham, MA, USA).

\section{Lipophilic-oxygen radical absorbance capacity (L-ORAC)}

The lipophilic antioxidant capacity was determined using the L-ORAC assay, ${ }^{29}$ with randomly methylated $\beta$-cyclodextrin (RMCD) as a solubility enhancer. ${ }^{30}$ The decay of the fluorescence spectra was obtained with a spectrofluorimeter (Victor X4, PerkinElmer, Waltham, MA, USA) at an excitation wavelength of $485 \mathrm{~nm}$ and an emission wavelength of $520 \mathrm{~nm}$.

The calibration curve for both assays was performed using Trolox (Sigma-Aldrich, St. Louis, MO, USA) as a reference standard and the results were expressed in Trolox equivalent antioxidant capacity per gram of oil.

\section{Statistical Analysis}

Data were expressed as mean values \pm standard deviations of the analytical error propagation. The results were submitted to analysis of variance (ANOVA) and mean values were compared by Tukey's test, using the Statistica software, version $8.0,{ }^{31}$ at $5 \%$ level of significance $(p<0.05)$ for rejection of the null hypothesis. The principal and interaction effects resulted of factorial design were calculated and the variance analysis was used to evaluate the effect of independent variables on the response using the mathematical model expressed by equation 1 :

$Y=\beta_{0}+\beta_{1} X_{1}+\beta_{2} X_{2}+\beta_{3} X_{3}+\beta_{12} X_{1} X_{2}+\beta_{13} X_{1} X_{3}+$

$\beta_{23} X_{2} X_{3}+\beta_{123} X_{1} X_{2} X_{3}+\varepsilon$

where $\mathrm{Y}$ is the expected response, $\mathrm{X}_{1}$ is the enzyme concentration, $\mathrm{X}_{2}$ is the sample/water ratio, $\mathrm{X}_{3}$ is the extraction time, and the other term refers to interactions effects.

\section{Results and Discussion}

Considering that the plant cell walls are mainly composed of proteins and polysaccharides, such as cellulose, hemicelluloses and pectins, ${ }^{32}$ the enzymatic extracts should contain enzymes with different activities. Therefore, Pectinex Ultra SPL (pectinase), Celluclast 1.5 L (cellulase) and Alcalase $2.4 \mathrm{~L}$ (protease) enzymes were chosen. Some parameters, such as the $\mathrm{pH}$ and optimal temperature of the enzymes, sample/water ratio and extraction time were also considered, since these conditions could affect the extraction yield of this process.

The data obtained, with a $2^{3}$ factorial design with center point in triplicate for sunflower oil extraction using enzymes, are shown in Table 2. Table 3 shows the ANOVA for the extraction yield of sunflower oil.

Table 2. Factorial design $2^{3}$ with center point and enzymatic aqueous extraction yield of sunflower oil

\begin{tabular}{lcccccccc}
\hline & \multicolumn{3}{c}{ Coded variable } & & \multicolumn{4}{c}{ Actual variable } \\
\cline { 2 - 6 } \cline { 6 - 8 } Run & $\mathrm{X}_{1}^{\mathrm{a}}$ & $\mathrm{X}_{2}^{\mathrm{b}}$ & $\mathrm{X}_{3}^{\mathrm{c}}$ & & $\mathrm{X}_{1}^{\mathrm{a}} / \%$ & $\begin{array}{c}\mathrm{X}_{2}^{\mathrm{b}} / \\
\left(\mathrm{g} \mathrm{mL}^{-1}\right)\end{array}$ & $\mathrm{X}_{3}^{\mathrm{c}} / \mathrm{h}$ & $\mathrm{Y}^{\mathrm{d}} / \%$ \\
\hline 1 & -1 & -1 & -1 & & 6 & $1 / 6$ & 4 & 27.4 \\
2 & +1 & -1 & -1 & & 10 & $1 / 6$ & 4 & 29.7 \\
3 & -1 & +1 & -1 & & 6 & $1 / 10$ & 4 & 22.3 \\
4 & +1 & +1 & -1 & & 10 & $1 / 10$ & 4 & 23.1 \\
5 & -1 & -1 & +1 & & 6 & $1 / 6$ & 8 & 34.7 \\
6 & +1 & -1 & +1 & & 10 & $1 / 6$ & 8 & 36.6 \\
7 & -1 & +1 & +1 & & 6 & $1 / 10$ & 8 & 29.4 \\
8 & +1 & +1 & +1 & & 10 & $1 / 10$ & 8 & 28.3 \\
9 & 0 & 0 & 0 & & 8 & $1 / 8$ & 6 & 27.6 \\
10 & 0 & 0 & 0 & & 8 & $1 / 8$ & 6 & 27.3 \\
11 & 0 & 0 & 0 & & 8 & $1 / 8$ & 6 & 27.3 \\
\hline
\end{tabular}

${ }^{\mathrm{a} E n z y m e ~ c o n c e n t r a t i o n ;}{ }^{\mathrm{b}} \mathrm{s}$ ample/water ratio; ${ }^{\mathrm{c} e x t r a c t i o n}$ time; ${ }^{\mathrm{d} e n z y m a t i c}$ aqueous extraction yield.

Table 3. Analysis of variance (ANOVA) for the response enzymatic aqueous extraction yield of sunflower oil

\begin{tabular}{lccccc}
\hline Source & $\begin{array}{c}\text { Degrees of } \\
\text { freedom }\end{array}$ & $\begin{array}{c}\text { Sum of } \\
\text { squares }\end{array}$ & $\begin{array}{c}\text { Mean } \\
\text { square }\end{array}$ & F-value & $p$-value \\
\hline $\mathrm{X}_{1}^{\mathrm{a}}$ & 1 & 1.78 & 1.78 & 5.60 & 0.0643 \\
$\mathrm{X}_{2}{ }^{\mathrm{b}}$ & 1 & 79.70 & 79.70 & 251.02 & $<0.0001$ \\
$\mathrm{X}_{3}{ }^{\mathrm{c}}$ & 1 & 87.98 & 87.98 & 277.11 & $<0.0001$ \\
$\mathrm{X}_{1} \mathrm{X}_{2}$ & 1 & 2.57 & 2.57 & 8.08 & 0.0361 \\
Curvature & 1 & 5.15 & 5.15 & 16.22 & 0.0100 \\
Residual & 5 & 1.59 & 0.32 & - & - \\
Lack of fit & 3 & 1.51 & 0.50 & 13.29 & 0.0708 \\
Pure error & 2 & 0.08 & 0.04 & - & - \\
\hline Total & 10 & 178.75 & - & - & - \\
\hline
\end{tabular}

${ }^{\mathrm{a} E n z y m e ~ c o n c e n t r a t i o n ; ~}{ }^{\mathrm{b}}$ sample/water ratio; ${ }^{\mathrm{c} e x t r a c t i o n}$ time. 
The highest yield obtained from the extraction of sunflower oil from the factorial design was $36.6 \%$ under these conditions: $10 \%$ of enzymes, a sample/water ratio of $1 / 6\left(\mathrm{~g} \mathrm{~mL}^{-1}\right)$ and eight hours of extraction.

The ANOVA for the enzymatic aqueous extraction of sunflower oil showed that the three terms in the study were significant for the model. The analysis of the effects showed that the extraction time and the sample/water ratio were the most significant factors of the extraction process with contributions of 49.22 and $44.58 \%$, respectively. The curvature of the model was significant (measured by difference between the average of the center points and the average of the factorial points) in the design space. The lack of fit was not significant and the mathematical equation and the regression coefficient obtained for this model are reported in equation 2 . The interaction effects which were not significant were removed from the model equation. The response surface is shown in Figure 1.

$\mathrm{Y}=28.95+0.47 \mathrm{X}_{1}-3.16 \mathrm{X}_{2}+3.32 \mathrm{X}_{3}-0.57 \mathrm{X}_{1} \mathrm{X}_{2}$

$\mathrm{R}^{2}=0.991$

where $\mathrm{Y}$ is the extraction yield, $\mathrm{X}_{1}$ is the enzyme concentration, $\mathrm{X}_{2}$ is the sample/water ratio and $\mathrm{X}_{3}$ is the extraction time.

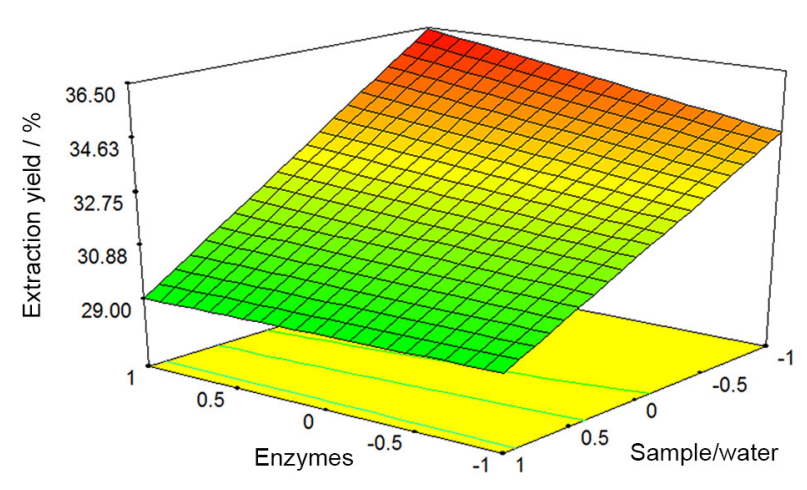

Figure 1 Response surface for the enzymatic aqueous extraction of sunflower oil.

Table 4 shows the yield obtained by different methods used in the extraction of sunflower oil.

Table 4. Extraction processes yield of sunflower oil obtained by different methods

\begin{tabular}{lc}
\hline Method & Yield /\% \\
\hline Solvent & $55.1^{\mathrm{a}} \pm 0.7$ \\
Pressing & $36.8^{\mathrm{b}} \pm 0.5$ \\
Enzymatic $^{\mathrm{a}}$ & $36.6^{\mathrm{b}} \pm 0.6$ \\
\hline
\end{tabular}

a Maximum extraction yield obtained from the factorial design. Mean $(n=3) \pm$ standard deviation. Different letters in the same column indicate significant difference by Tukey's test $(p<0.05)$.
No significant difference between the pressing and enzymatic techniques was observed, showing that enzymatic method under the evaluated conditions could extract the same amount of oil as conventional methodology.

Several studies claim that it is not possible to compare the antioxidant capacity quantitatively among different techniques, because of differences between the methodologies (solvents, types of radicals and different targets of oxidation). Therefore, it is recommended to perform at least two or, if possible, all of the most widely used assays, as DPPH, ferric reducing antioxidant power (FRAP), ORAC and 2,2'-azinobis(3-ethylbenzothiazoline-6-sulphonic acid (ABTS), for vegetable oils to obtain more complete information about the antioxidant capacity of the oils. ${ }^{33,34}$

To evaluate the antioxidant capacity of the sunflower oil extracted, either enzymatically or via conventional methods, two assays were performed: DPPH radical scavenging activity and antioxidant activity by inhibiting oxidation induced by peroxyl radical using the L-ORAC assay. Table 5 shows the results obtained from these tests.

Table 5. Antioxidant capacity of sunflower oil extracted by different methods

\begin{tabular}{lcc}
\hline \multirow{2}{*}{ Method } & \multicolumn{2}{c}{ Assay / $\left(\mu \mathrm{mol}\right.$ Trolox $\mathrm{g}^{-1}$ of oil $)$} \\
\cline { 2 - 3 } Solvent & \multicolumn{1}{c}{ DPPH } & L-ORAC \\
Pressing & $86.71^{\mathrm{b}} \pm 3.54$ & $225.71^{\mathrm{b}} \pm 2.68$ \\
Enzymatic & $106.18^{\mathrm{a}} \pm 3.89$ & $181.94^{\mathrm{c}} \pm 11.11$ \\
\hline
\end{tabular}

DPPH: 2,2-diphenyl-1-picrylhydrazyl; L-ORAC: lipophilic-oxygen radical absorbance capacity. Mean $(n=3) \pm$ standard deviation. Different letters in the same column indicate significant difference by Tukey's test $(p<0.05)$.

The sunflower oil showed the highest antioxidant capacity against the DPPH radical when extracted by a pressing process. In relation to solvents and enzymatic methods, the values reported were considered statistically equal by Tukey's test at $95 \%$ confidence. For the L-ORAC assay, the oil obtained by enzymatic aqueous extraction showed the highest antioxidant capacity against the peroxyl radical, being 1.6 times higher than the antioxidant capacity of the oil extracted using solvents and about twice as high as that obtained by pressing.

The sunflower oil that presents the greatest antioxidant capacity brings more health benefits, since the natural antioxidants have the potential effect in preventing chronic diseases, being capable of protecting biological systems against the action of reactive oxygen species and nitrogen, which are responsible for oxidative damage to lipids, proteins and nucleic acids. ${ }^{35,36}$ Furthermore, it shows higher protection against the action of free radicals that initiate and 
Table 6. Quantification of phytosterols and tocopherols of sunflower oil

\begin{tabular}{|c|c|c|c|c|c|}
\hline \multirow{2}{*}{ Method } & \multirow{2}{*}{$\begin{array}{l}\alpha \text {-Tocopherol / } \\
\left(\mathrm{mg} 100 \mathrm{~g}^{-1}\right)\end{array}$} & \multicolumn{3}{|c|}{ Phytosterol / (mg $\left.100 \mathrm{~g}^{-1}\right)$} & \multirow{2}{*}{$\begin{array}{l}\text { Total phytosterol / } \\
\quad\left(\mathrm{mg} 100 \mathrm{~g}^{-1}\right)\end{array}$} \\
\hline & & Campesterol & Stigmasterol & Sitosterol & \\
\hline Solvent & $48.46^{\mathrm{a}} \pm 2.38$ & $17.17^{\mathrm{a}} \pm 2.16$ & $19.75^{\mathrm{a}} \pm 1.27$ & $130.03^{\mathrm{b}} \pm 3.75$ & $166.95^{\mathrm{b}} \pm 3.65$ \\
\hline Pressing & $48.69^{\mathrm{a}} \pm 5.43$ & $17.29^{\mathrm{a}} \pm 3.31$ & $17.16^{\mathrm{a}} \pm 2.06$ & $121.06^{\mathrm{b}} \pm 1.29$ & $155.52^{\mathrm{b}} \pm 4.01$ \\
\hline Enzymatic & $40.84^{\mathrm{b}} \pm 0.17$ & $19.85^{\mathrm{a}} \pm 0.99$ & $19.34^{\mathrm{a}} \pm 1.30$ & $143.81^{\mathrm{a}} \pm 6.70$ & $183.00^{\mathrm{a}} \pm 6.90$ \\
\hline
\end{tabular}

Mean $(n=3) \pm$ standard deviation. Different letters in the same column indicate significant difference by Tukey's test $(p<0.05)$.

perpetuate lipid peroxidation, which consists in the main form of degradation of vegetable oils and an important source of losses to the food industry. ${ }^{37}$

The $\alpha$-tocopherol and the three major phytosterols (campesterol, stigmasterol and sitosterol) were identified in sunflower oil. Table 6 shows the quantification of these compounds in the oil sample.

In relation to the $\alpha$-tocopherol in the sunflower oil, the pressing and solvent methods were able to extract the largest amount of this compound. Tuberoso et al. ${ }^{38}$ identified the $\alpha$-tocopherol using high-performance liquid chromatography (HPLC) with fluorescence detector in sunflower oil obtained by pressing grains and obtained $49.42 \mathrm{mg}$ of this compound in $100 \mathrm{~g}$ of oil, a value very close to that determined in this work using GC-MS.

The phytosterols present in sunflower oil, evaluated separately, did not show significant differences between the extraction methods, solvents, pressing and enzymatic, except for $\beta$-sitosterol, in which the oil extracted with enzymes showed the highest amount. Phillips et al. ${ }^{39}$ evaluated the composition of sterols in several edible oils and analyzed the main phytosterols in refined sunflower oil. The results obtained in the present study for all extraction methodologies were higher in sunflower oil without a refining process. The authors affirm that the refining stage could cause a reduction in the amount of total and free sterols in edible oils.

Table 7 shows the results of the fatty acid quantification of the sunflower oil extraction using solvent, pressing and enzymatic aqueous extraction methods.

The statistical analysis indicated that there was significant variation in some fatty acids among the different methodologies for the oilseed under study. The sunflower oil composition was mainly the fatty acids 16:0, 18:0, 18:1n-9 and 18:2n-6, showing differences among the methods only for the $16: 0$ fatty acid content. Nimet et al. ${ }^{40}$ who evaluated the extraction of sunflower oil by supercritical and subcritical $\left(\mathrm{CO}_{2}\right.$ and propane), and Corsini and Jorge, ${ }^{41}$ who studied changes in the profile of fatty acids of sunflower oil used in frying, also reported the same fatty acids as those mentioned above.
Table 7. Fatty acid quantification of sunflower oil

\begin{tabular}{|c|c|c|c|}
\hline \multirow{2}{*}{ Fatty acid } & \multicolumn{3}{|c|}{ Method / (mg g ${ }^{-1}$ total lipids) } \\
\hline & Solvent & Pressing & Enzymatic \\
\hline 14:0 & $0.667^{\mathrm{a}} \pm 0.005$ & $0.666^{\mathrm{a}} \pm 0.016$ & $0.632^{\mathrm{a}} \pm 0.028$ \\
\hline 15:0 & $0.118^{\mathrm{b}} \pm 0.002$ & $0.133^{\mathrm{a}} \pm 0.003$ & $0.107^{c} \pm 0.009$ \\
\hline 16:0 & $52.836^{\mathrm{a}} \pm 0.246$ & $49.999^{c} \pm 0.427$ & $51.070^{\mathrm{b}} \pm 0.382$ \\
\hline $16: 1 n-7$ & $1.207^{\mathrm{b}} \pm 0.037$ & $1.347^{\mathrm{a}} \pm 0.030$ & $1.240^{\mathrm{b}} \pm 0.016$ \\
\hline 17:0 & $0.387^{\mathrm{b}} \pm 0.002$ & $0.453^{\mathrm{a}} \pm 0.033$ & $0.444^{\mathrm{a}} \pm 0.015$ \\
\hline $17: 1 \mathrm{n}-7$ & $0.384^{\mathrm{a}} \pm 0.014$ & $0.411^{\mathrm{a}} \pm 0.037$ & $0.387^{\mathrm{a}} \pm 0.022$ \\
\hline 18:0 & $31.612^{\mathrm{a}} \pm 0.600$ & $30.338^{\mathrm{a}} \pm 0.255$ & $30.628^{a} \pm 0.645$ \\
\hline 18:1n-9 & $561.817^{\mathrm{a}} \pm 4.316$ & $560.623^{\mathrm{a}} \pm 1.572$ & $559.393^{\mathrm{a}} \pm 1.948$ \\
\hline $18: 1 \mathrm{n}-7$ & $3.611^{\mathrm{b}} \pm 0.121$ & $4.322^{\mathrm{a}} \pm 0.165$ & $4.293^{\mathrm{a}} \pm 0.160$ \\
\hline $18: 2 n-6$ & $294.466^{\mathrm{a}} \pm 6.095$ & $299.332^{\mathrm{a}} \pm 2.012$ & $301.753^{\mathrm{a}} \pm 3.353$ \\
\hline $18: 3 n-3$ & $0.246^{\mathrm{a}} \pm 0.009$ & $0.259^{\mathrm{a}} \pm 0.009$ & $0.226^{\mathrm{b}} \pm 0.007$ \\
\hline 20:0 & $1.811^{\mathrm{b}} \pm 0.064$ & $1.892^{\mathrm{b}} \pm 0.029$ & $2.102^{\mathrm{a}} \pm 0.029$ \\
\hline $20: 1 \mathrm{n}-9$ & $1.362^{\mathrm{a}} \pm 0.039$ & $1.383^{\mathrm{a}} \pm 0.047$ & $1.477^{\mathrm{a}} \pm 0.064$ \\
\hline $20: 4 n-6$ & $6.755^{\mathrm{a}} \pm 0.099$ & $6.206^{\mathrm{b}} \pm 0.051$ & $6.181^{b} \pm 0.143$ \\
\hline $20: 5 n-3$ & $0.194^{\mathrm{c}} \pm 0.008$ & $0.296^{\mathrm{b}} \pm 0.015$ & $0.343^{\mathrm{a}} \pm 0.011$ \\
\hline \multirow[t]{2}{*}{ 24:0 } & $2.150^{\mathrm{a}} \pm 0.082$ & $1.944^{\mathrm{ab}} \pm 0.055$ & $1.988^{\mathrm{b}} \pm 0.074$ \\
\hline & \multicolumn{3}{|c|}{ Summations and ratios / ( $\mathrm{mg} \mathrm{g}^{-1}$ total lipids) } \\
\hline SFA & $89.582^{\mathrm{a}} \pm 0.655$ & $85.425^{\mathrm{b}} \pm 0.500$ & $86.971^{\mathrm{b}} \pm 0.755$ \\
\hline MUFA & $568.382^{\mathrm{a}} \pm 4.317$ & $568.087^{\mathrm{a}} \pm 1.577$ & $566.789^{\mathrm{a}} \pm 1.955$ \\
\hline PUFA & $301.661^{\mathrm{a}} \pm 6.096$ & $306.093^{\mathrm{a}} \pm 2.013$ & $308.502^{\mathrm{a}} \pm 3.356$ \\
\hline$n-6$ & $301.222^{\mathrm{a}} \pm 6.096$ & $305.538^{\mathrm{a}} \pm 2.013$ & $307.934^{\mathrm{a}} \pm 3.356$ \\
\hline$n-3$ & $0.440^{\mathrm{b}} \pm 0.010$ & $0.555^{\mathrm{a}} \pm 0.016$ & $0.568^{\mathrm{a}} \pm 0.009$ \\
\hline$n-6 / n-3$ & $685.312^{\mathrm{a}} \pm 21.287$ & $551.134^{\mathrm{b}} \pm 16.674$ & $542.011^{\mathrm{b}} \pm 10.495$ \\
\hline PUFA/SFA & $3.368^{\mathrm{b}} \pm 0.072$ & $3.583^{\mathrm{a}} \pm 0.032$ & $3.548^{\mathrm{a}} \pm 0.049$ \\
\hline
\end{tabular}

SFA: total saturated fatty acids; MUFA: total monounsaturated fatty acids; PUFA: total polyunsaturated fatty acids; $n-6$ : total omega- 6 fatty acids; $\mathrm{n}-3$ : total of omega-3 fatty acids. Mean $(\mathrm{n}=3) \pm$ standard deviation. Different letters in the same column indicate significant difference by Tukey's test $(p<0.05)$.

The presence of the linoleic $(18: 2 n-6)$ and $\alpha$-linolenic (18:3n-3) fatty acids was identified in sunflower oil. These fatty acids are extremely important in the human diet in the synthesis of other long chain fatty acid routes, such as $22: 6 n-3$ and $22: 5 n-3$, which play an important role in preventing inflammation and fostering immunity. ${ }^{42,43}$ 
The sunflower oil extracted using enzymes showed the highest amount of the 20:5n-3 fatty acid ( $\left.0.568 \mathrm{mg} \mathrm{g}^{-1}\right)$, reflected in the omega-3 summation. A diet that contains omega- 3 and polyunsaturated fatty acids brings health benefits, such as reducing the risk of coronary artery disease, increase of high density lipoprotein (HDL), stabilization of heartbeat, hypertension control, prevention of cancers, lower effects of autoimmune diseases, relief of depression, help maintain under normal conditions, cell membranes, brain function, nerve impulse transmission, and participate in the transfer of atmospheric oxygen to the blood plasma, synthesis of hemoglobin and cell division. $^{42,44,45}$

\section{Conclusions}

The experimental design used for the enzymatic aqueous extraction proved adequate to evaluate the influence of the independent variables in the enzymatic process. The terms that most influenced the response were the sample/water ratio and the extraction time, whereby the reduction in the sample/water ratio and the increase in time favored higher extraction yields.

The sunflower oil extracted using enzymes and nontoxic solvents showed the highest antioxidant capacity against peroxyl radicals, total phytosterols and omega-3 fatty acids contents, as well as the lowest content of saturated fatty acids, when compared with the oil obtained by conventional methods. Therefore, the application of enzymes for sunflower oil extraction could indeed represent a promising alternative that is environmentally friendly and free of toxic solvent residues, and provides a final product of high quality.

\section{Acknowledgments}

The authors thank Coordination for the Improvement of Higher Education Personnel (CAPES) and the National Council for Scientific and Technological Development (CNPq) for the financial support.

\section{References}

1. http://www.embrapa.br/soja/cultivos/girassol accessed in November 2015.

2. http://faostat3.fao.org/browse/Q/QC/E accessed in November 2015.

3. Parmentier, M.; Guillemin, S.; Barbar, R.; Linder, M.; Fanni, J.; Ol., Corps Gras, Lipides 2004, 11, 377.

4. Gaia, Q.-Y.; Jiao, J.; Mua, P.-S.; Wanga, W.; Luo, M.; Li, C.-Y.; Zu, Y.-G.; Wei, F.-Y.; Fu, Y.-J.; Ind. Crops Prod. 2013, 45, 303.
5. Rai, A.; Mohanty, B.; Bhargava, R.; Food Chem. 2016, 192, 647.

6. http://www.botaneco.com/index-10.html accessed in November 2015.

7. Ribeiro, S. A. O.; Nicacio, A. E.; Zanqui, A. B.; Biondo, P. B. F.; Abreu-Filho, B. A.; Visentainer, J. V.; Gomes, S. T. M.; Matsushita, M.; LWT -- Food Sci. Technol. 2016, 65, 464.

8. Li, J.; Zu, Y.-G.; Luo, M.; Gu, C-B.; Zhao, C-J.; Efferth, T.; Fu, Y.-J.; Food Chem. 2013, 138, 2152.

9. Teixeira, C. B.; Macedo, G. A.; Macedo, J. A.; Silva, L. H. M.; Rodrigues, A. M. C.; Bioresour. Technol. 2013, 129, 575.

10. Bansal, N.; Tewari, R.; Soni, R.; Soni, S. K.; Waste Manage. 2012, 32, 1341.

11. Thomas, L.; Larroche, C.; Pandey, A.; Biochem. Eng. J. 2013, $81,146$.

12. Hansen, G. H.; Lübeck, M.; Frisvada, J. C.; Lübeck, P. S.; Andersen, B.; Process Biochem. (Oxford, U. K.) 2015, 50, 1327.

13. Zhang, Y.-L.; Li, S.; Yin, C.-P.; Jiang, D.-H.; Yan, F.-F.; Xu, T.; Food Chem. 2012, 135, 304.

14. Zhang, S. B.; Liu, X. J.; Lu, Q. Y.; Wang, Z. W.; Zhao, X.; J. Am. Oil Chem. Soc. 2013, 90, 1261.

15. Stat-Ease, Inc; Design Expert Software version 7.1.3; Minneapolis, USA, 2008.

16. Santos, R. D.; Ferrari, R. A.; Food Sci. Technol. 2005, 25, 132.

17. Bligh, E. G.; Dyer, W. J.; Can. J. Biochem. Physiol. 1959, 37, 911.

18. Hartman, L.; Lago, R. C. A.; Lab. Pract. 1973, 22, 475.

19. Sargi, S. C.; Silva, B. C.; Santos, H. M. C.; Montanher, P. F.; Boeing, J. S.; Santos-Júnior, O. O.; Souza, N. E.; Visentainer, J. V.; Food Sci. Technol. 2013, 33, 541.

20. Joseph, J. D.; Ackman, R. G.; J. AOAC Int. 1992, 75, 488.

21. Visentainer, J. V.; Quim. Nova 2012, 35, 274.

22. Du, M.; Ahn, D. U.; J. Food Sci. 2002, 67, 1696.

23. Beveridge, T. H. J.; Li, T. S. C.; Drover, J. C. G.; J. Agric. Food Chem. 2002, 50, 744.

24. Zanqui, A. B.; Moraes, D. R.; Silva, C. M.; Santos, J. M.; Gomes, S. T. M.; Visentainer, J. V.; Eberlin, M. N.; Cardozo-Filho, L.; Matsushita, M.; Food Chem. 2015, 188, 452.

25. Li, T. S. C.; Beveridge, T. H. J.; Drover, J. C. G.; Food Chem. 2007, 101, 1633.

26. Brand-Williams, W.; Cuvelier, M. E.; Berset, C.; Food Sci. Technol. 1995, 28, 25.

27. Masuda, T.; Yonemori, S.; Oyama, Y.; Takeda, Y.; Tanaka, T.; Andoh, T.; J. Agric. Food Chem. 1999, 47, 1749.

28. Ma, X.; Wu, H.; Liu, L.; Yao, Q.; Wang, S.; Zhan, R.; Xing, S.; Zhou, Y.; Sci. Horticult. (Amsterdam, Neth) 2011, 129, 102.

29. Prior, R. L.; Hoang, H.; Gu, L.; Wu, X.; Bacchiocca, M.; Howard, L.; Hampsch-Woodill, M.; Huang, D.; Ou, B.; Jacob, R.; J. Agric. Food Chem. 2003, 51, 3273.

30. Huang, D.; Ou, B.; Hampsch-Woodill, M.; Flanagan, J. A.; Deemer, E. K.; J. Agric. Food Chem. 2002, 50, 1815. 
31. StatSoft, Inc.; Statistica: Data Analysis Software System, version 8.0; Tulsa, USA, 2007.

32. Taiz, L.; Zeiger, E.; Plant Physiology, $3^{\text {rd }}$ ed.; Sinauer Associates: Massachusetts, 2002.

33. Alves, C. Q.; David, J. M.; David, J. P.; Bahia, M. V.; Aguiar, R. M.; Quim. Nova 2010, 33, 2202.

34. Castelo-Branco, V. N.; Torres, A. G.; Rev. Nutr. 2011, 24, 173.

35. Szydlowska-Czerniak, A.; Karlovits, G.; Dianoczki, C.; Recseg, K.; Szlyk, E.; J. Am. Oil Chem. Soc. 2008, 85, 141.

36. Ramadan, M. F.; Moersel, J. T.; J. Food Compos. Anal. 2006, 19,838 .

37. Chaiyasit, W.; Elias, R. J.; McClements, D. J.; Decker, E. A.; Crit. Rev. Food Sci. Nutr. 2007, 47, 299.

38. Tuberoso, C. I. G.; Kowalczyk, A.; Sarritzu, E.; Cabras, P.; Food Chem. 2007, 103, 1494.

39. Phillips, K. M.; Ruggio, D. M.; Toivo, J. I.; Swank, M. A.; Simpkins, A. H.; J. Food Compos. Anal. 2002, 15, 123.
40. Nimet, G.; Silva, E. A.; Palú, F.; Dariva, C.; Freitas, L. S.; Medina-Neto, A.; Cardozo-Filho, L.; Chem. Eng. J. (Amsterdam, Neth.) 2011, 168, 262.

41. Corsini, M. S.; Jorge, N.; Quim. Nova 2008, 31, 956.

42. Pratt, S.; Matthews, K.; Super Alimentos: os Incríveis Efeitos de uma Comida que Pode Mudar Sua Vida, $1^{\mathrm{a}}$ ed.; Prestígio Editorial: São Paulo, 2005.

43. Simopoulos, A. P.; Food Rev. Int. 2004, 20, 77.

44. Yehuda, S.; Rabinovitz, S.; Carasso, R. L.; Mostofsky, D. I.; Neurobiol. Aging 2002, 23, 843.

45. Youdim, K. A.; Martin, A.; Joseph, J. A.; Int. J. Dev. Neurosci. 2000, 18, 383.

Submitted: September 23, 2015

Published online: November 30, 2015 